\title{
FOLIAR SULPHUR APPLICATION AND ITS TIMINGS IMPROVE WHEAT (TRITICUM AESTIVUM L.) PRODUCTIVITY IN SEMI- ARID CLIMATE
}

\author{
SHAH, S. A. A. ${ }^{1,2^{*}}-$ MIAN, I. A. ${ }^{2}-$ SHARIF, M. ${ }^{2}-$ IQBAL, A. ${ }^{3}-$ SHAH, ${ }^{2}-$ SHAH, S. A. A. ${ }^{4}-$ \\ ABRAR, M. M. ${ }^{1}-$ MUSTAFA, A. ${ }^{1}-$ XU, M. ${ }^{1,5^{*}}$ \\ ${ }^{I}$ National Engineering Laboratory for Improving Quality of Arable Land, Institute of \\ Agricultural Resources and Regional Planning, Chinese Academy of Agricultural Sciences, \\ Beijing 100081, China \\ ${ }^{2}$ Department of Soil and Environmental Sciences, The University of Agriculture, Peshawar- \\ KPK, Pakistan \\ ${ }^{3}$ State Key Laboratory of Cotton Biology, Institute of Cotton Research of CAAS, Anyang, Henan \\ 455000, China \\ ${ }^{4}$ Department of Vegetable Sciences, College of Horticulture, China Agriculture University, \\ Beijing, China \\ ${ }^{5}$ South Subtropical Crop Research Institute, Chinese Academy of Tropical Agricultural Sciences \\ (CATAS), Zhanjiang, GuangDong 524091, China \\ *Corresponding authors \\ e-mail:xuminggang@caas.cn, shah_syed18@yahoo.com \\ (Received 21 ${ }^{\text {st }}$ Sep 2019; accepted 23 ${ }^{\text {rd }}$ Jan 2020)
}

\begin{abstract}
Sulphur fertilization is beneficial for improving growth, yield and yield determining components of field crops under a semiarid climate. The present field experiment was conducted to investigate the response to the foliar application of sulphur at various phenological stages of wheat. For this purpose, five treatments were explored i.e., control (no spray); water spray; $7.5 \mathrm{~kg} \mathrm{~S} \mathrm{ha}^{-1} ; 15 \mathrm{~kg} \mathrm{~S} \mathrm{ha}^{-1} ; 21 \mathrm{~kg} \mathrm{~S} \mathrm{ha}^{-1}$. The results revealed that the application of foliar sulphur at the rate of $15 \mathrm{~kg} \mathrm{ha}^{-1}$ increased the yield components (grain yield and biological yield) of wheat by 31 and $9 \%$ compared to control. The following trend $\left(15 \mathrm{~kg} \mathrm{~S} \mathrm{ha}^{-1}>21 \mathrm{~kg} \mathrm{~S} h a^{-1}>7.5 \mathrm{~kg} \mathrm{~S} \mathrm{ha}^{-1}>\right.$ water spray > control) was observed for the yield components. Conversely, the application of sulphur at $21 \mathrm{~kg} \mathrm{ha}^{-1}$ increased the concentration of sulphur in soil and plant by 104 and 195\% respectively, compared to control. A positive linear relationship was observed between soil sulphur and grain yield of wheat $\left(\mathrm{R}^{2}=0.76\right.$ and $\left.\mathrm{P}<0.0001\right)$. Furthermore, it was observed that the growth and yield of wheat increased significantly when foliar sulphur was applied in two equal splits (50\% each at tillering and booting) compared to the full application at tillering and booting. It was inferred from this study that application of foliar sulphur at the rate of $15 \mathrm{~kg} \mathrm{ha}^{-1}$ in two equal splits (50\% each at tillering and booting) improves growth and productivity of wheat in the semiarid climate.
\end{abstract}

Keywords: foliar, sulphur, application timing, wheat, phenology

\section{Introduction}

The ongoing globalization with the ever increasing human population are threatening the food security and environmental quality. It is estimated that the world's population may reach to 9.1 billion (34\% higher than today) by 2050 . These trends show that the demand for food would continue to grow to feed both the humans and animals as well (Tilman et al., 2011). The desired increase in agricultural production to meet global 
food demand casts immense pressure on the sparse resources that are already on the edge to be endangered. Meanwhile, the agricultural intensification to get more production have shown certain drawbacks in the form of environmental degradation (Davidson, 2009), damages to the biodiversity (Christopher and Tilman, 2008) and degradation of land and water resources which are increasing continuously and are even stagnant in some countries (Diaz and Rosenberg, 2008; Guo et al., 2010; Mustafa et al., 2019a). Agriculture is the mainstay of Pakistan's national economy. It is a major contributor to support Pakistan's population and to food security accounting for $20.9 \%$ share to country's GDP (GOP, 2015; Chandio et al., 2016).

Wheat (Triticum aestivum L.) is the world's most important cereal crop. In Pakistan, wheat is also the main staple crop of the people, meeting $95 \%$ of the country's food demand (Malik et al., 2006). It also occupies a significant position due to largest area under single crop cultivation (Mustafa et al., 2019b). Its agricultural added value accounts for $10.1 \%$, about $2.1 \%$ of the GDP reached the planting area is 9.18 million ha 1 in 2014-2015, and the average yield was $2852 \mathrm{~kg} \mathrm{ha}^{-1}$ (MNFSR, 2014-15). These figures are not satisfactory because the country's average wheat yield is lower than that of some major wheat producers in the world, such as France, Mexico, China and the United States (Kakar et al., 2015). The factors contributing to the low yields in Pakistan are the lack of education to apply appropriate doses of fertilizer at different stages of the crop and over time. As a result, smallholders are facing certain socio-economic constraints, lack of extension services, inability to obtain high-quality seeds during the growth period and increasing costs of fertilizer (Pathak et al., 2006).

Since wheat is an exhaustive crop, this means it reduces the soil fertility and productivity leading to reduced crop yields. It is very important to evaluate the soil fertility status of main wheat producing areas. In fact, due to its frequent scarcity in time and space, sulphur is of great significance all over the world. Though sulphur is required in lesser amounts for optimum wheat growth, yet its concentration is low in world soils causing potential reductions in attainable yields. Various aspects contribute to the deficiencies of $S$, such as the high chemical fertilizer usage without $S$, several types and excessive planting intensity, and the treatment, leaching and erosion from crop residues for feed and fuel (Tandon, 1984). Sulphur plays an important role in the major functions of plant growth, metabolism, and enzymatic reactions (Mengal and Kirkby, 1987). Without sulphur, the activity of sulphur-containing amino acids such as cysteine, cysteine, and methionine would not be possible. Sulphur is an ingredient particularly involved in sglycosides, co enzyme, vitamin biotin, and thiamine (Tisdale et al., 1985).

Sulphur can also be used as a foliar application in order to ensure higher crop productivity. Leaf surface application of $S$ have shown the potential to control mildew stage of Erysiphe graminis (Hussain and Leitch, 2005) at the top of the canopy in terms of disease control. Moreover, foliar application of $\mathrm{S}$ improved the efficiency of fungicides (Zahid and Leitch, 2005). At the best time for wheat, foliar application of S can improve grain protein content and improve the production quality of bread wheat (Zahid and Leitch, 2005). Thus, there is a great scope to be find best application methods and timings to ensure maximum wheat production per unit utilization of $S$ fertilizer. The response of wheat bread quality to $S$ is more general than that of grain yield. The use of $\mathrm{S}$ does not directly affect grain protein concentration, but increases the weight of gelatinous protein in flour and the ratio of polymeric protein (Saeed et al., 2013). Sulphur deficiency may lead to harder grains, and the dough made from these grains is usually hard and non-elastic (Ryant and Hrivna, 2004). After applying S, the 
total absorption and concentration of S tended to be increased (Zahid and Leitch, 2005), hence improving the quality of wheat grains.

Foliar fertilization (provision of nutrients through aerial plant parts) has been considered an efficient technique which enhances availability of nutrients, use efficiencies and hence the subsequent crop yields (Saeed et al., 2012; Aziz et al., 2018). Studies on appropriate levels and timings of sulphur spraying in agroecological wheat growing areas in Khyber Pakhtunkhwa, Pakistan, have not been carried out earlier. In addition, little is known on how to ensure greater nutrient use efficiency via reduced nutrient losses have been remained neglected in the past especially in the area under consideration. Moreover, there is also a need to explore foliarly applied $\mathrm{S}$ at different growth stages of wheat in order to ensure maximum crop productivity. Therefore, present study was aimed to evaluate the response rate of foliar application of sulphur and its application timings on growth, phenology and yield of wheat which was grown as a reference crop.

\section{Materials and methods}

\section{Experimental site characteristics}

To study the effect of foliar sulphur and its application timings on yield and yield components of wheat, present field experiment was conducted at New Developmental Farm, The University of Agriculture Peshawar, Pakistan during 2013-2014 in winter season. In the mid of November, 2013, wheat seeds were sown in the field and the crop was harvested in the mid of May, 2014. The research farm is located at $34.01^{\circ} \mathrm{N}$, $71.35^{\circ} \mathrm{E}$, at an altitude of $350 \mathrm{~m}$ above sea level in the Peshawar valley. Peshawar is located about $1600 \mathrm{~km}$ north of the Indian ocean and has semiarid climate. The research farm is irrigated by the Warsak canal linked to Kabul river. Soil particle analysis (Gee and Bauder, 1979) revealed that the texture of soil was clay loam, alkaline ( $\mathrm{pH} \mathrm{8.2)} \mathrm{in}$ nature, calcareous, with a low organic matter content of $8.7 \mathrm{~g} \mathrm{~kg}^{-1}$ (Amanullah et al., 2009), total $\mathrm{N}$ content of $0.07 \%$, low concentrations of available phosphorus of $6.57 \mathrm{mg} \mathrm{kg}^{-1}$ measured by following the method of (Watanabe and Olsen, 1965) and exchangeable potassium of $121 \mathrm{mg} \mathrm{kg}^{-1}$ by following the method given by Simard (1993) on atomic absorption spectrophotometer. The climate of the area is semiarid where the mean annual rainfall is very low (300 to $500 \mathrm{~mm}$ ), 60-70\% of which occurs in summer, while the remaining 30-40\% rainfall occurs in winter (Amanullah et al., 2016).

\section{Experimental design and crop establishment}

The experiment was laid out in randomized complete block design having three replications. Each replication was consisted of 5 treatments viz five foliar sulphur levels (no spray, water spray, 7.5, 15 and $21 \mathrm{~kg} \mathrm{~S} \mathrm{ha}^{-1}$ ) and three application times at specific wheat growth stages (tillering, booting and half at tillering + half at booting stage). Sublimed sulphur (Analar) was used as a source for $\mathrm{S}$ containing $\left(200 \mathrm{~g} \mathrm{~L}^{-1}\right) \mathrm{S}$.

Plot size of $4 \mathrm{~m} \times 3 \mathrm{~m}$ (10 rows, $4 \mathrm{~m}$ long and $30 \mathrm{~cm}$ apart) was used. The recommended doses of $120 \mathrm{~kg} \mathrm{~N} \mathrm{ha}^{-1}$ (as urea), $90 \mathrm{~kg} \mathrm{P} \mathrm{ha}^{-1}$ (as ammonium phosphate) and $60 \mathrm{~kg} \mathrm{~K} \mathrm{ha}^{-1}$ (as potassium sulphate) were applied (Mustafa et al., 2019b). The required nitrogen was applied in two equal splits i.e. 50\% at sowing and 50\% at 30 days after sowing. Seeds of wheat verity (Atta Habib) kindly donated by Department of Agronomy, University of Agriculture, Peshawar, Pakistan were sown at the seed rate of 
$120 \mathrm{~kg} \mathrm{ha}^{-1}$. All other agronomic practices i.e. seed bed preparation, irrigations, hoeing and weeding were practiced uniformly to all the plots throughout the growth period for maximum yield. Good quality canal water was used for irrigation and crop protection measures were carried out as and when required throughout the experimental duration.

\section{Plant growth, phenological and yield attribute recordings}

Certain growth, yield and phenological observations were recorded as and when required on specific crop growth periods. Days to heading were recorded in each sub plot after completion of $80 \%$ heading. The number of days to heading was counted from the date of sowing to the date when $50 \%$ heading were completed in each subplot. The days to physiological maturity were recorded by counting the days from date of sowing to the date when plants become physiologically mature. Complete loss of the green color of glumes was used as indication of physiological maturity. Data on plant height were recorded by measuring randomly selected 10 plants in each subplot from base of plant to the tip of spikes excluding awns at maturity. The internode lengths of five randomly selected tillers was measured with the help of meter rod and then averaged accordingly. Data on number of tillers were recorded by counting the numbers of tillers in central three rows of each sub plot, and were converted to numbers of tillers $\mathrm{m}^{-2}$. Data on number of spikes $\mathrm{m}^{-2}$ was recorded by counting the number of spikes in three randomly selected rows of one-meter length and were converted into spikes $\mathrm{m}^{-2}$. Grains from five randomly selected spikes were obtained by hand threshing and was counted and converted into average number of grains spike ${ }^{-1}$. Thousand grains were counted from the grains randomly picked from each sub plot and weighed with a digital balance. Four central rows were harvested in each subplot and was sun dried and bundles were weighed. Small wheat thresher was used for threshing the biological yield taken from four central rows in each sub plot. After threshing the grains were weighed by balance and converted to $\mathrm{kg} \mathrm{ha}^{-1}$ by using the formula:

$$
\text { Grain yield }\left(\mathrm{kg} \mathrm{ha}^{-1}\right)=\frac{\text { Grain yield in four central rows }}{\mathrm{R}-\mathrm{R} \times \text { No of rows } \times \text { row length }} \times 1000
$$

Harvest index were calculated as the ratio of grain yield to the total biological yield and expressed as percentage.

The sampling of leaf was accomplished by collecting matured 10 leaves from healthy and suitable plants from each plot in the field. The central rows were selected and collect leaves for leaf sampling and these samples were than analyzed for $\mathrm{SO}_{4}-\mathrm{S}$ in the tissues of leaf.

\section{Soil analysis}

For soil analysis a composite sample at the depth of $15 \mathrm{~cm}$ was randomly taken from the experimental field before sowing of crop and was analyzed to major physiochemical properties of the soil. Post-harvest soil sample from each experimental unit was also taken and analyzed for soil and leaf sulphur content. Completely oven dried ground leaf samples up to 0.5 depth were used in a $150 \mathrm{ml}$ conical flask. $15 \mathrm{ml}$ concentrated $\mathrm{HNO}_{3}$ was placed into the flask for overnight, $2 \mathrm{~mL}$ concentrated $\mathrm{H}_{2} \mathrm{SO}_{4}$ along with $5 \mathrm{~mL}$ per chloric acid was heated up eventually digested until visible massive gases as well as the gases layering inside the beaker appeared. Then the sample was cooled and $50 \mathrm{ml}$ distilled water was added and heated again. The sample was 
filtered by using Whatmann filter paper \# 40. The filtrate was obtained in a volumetric flask then the essential volume was produced by putting distilled water (Richard, 1954). Soil sulphate form of $\mathrm{S}$ was determined by the method described by Rayan et al. (2001).

\section{Statistical analyses}

The data recorded for each parameter were analyzed statistically by using Statistix ${ }^{\circledR}$ 8.1 software and means were compared by using fisher protected least significance difference (LSD) test at 5\% level of significance (Steel and Torrie, 1980). The analysis of correlation was performed by using sigma-stat function in sigma plot 14.0 software for windows. A simple linear regression was used to evaluate the relationship between the sulphur concentration and yield of wheat. According to the linear model based on a firstorder kinetics equation $(\mathrm{Y}=\mathrm{a}+\mathrm{bx})$, where $\mathrm{a}$ is intercept and $\mathrm{b}$ is slope and both are constants). We used probability level $(\mathrm{P}<0.01)$ for considering the significant result.

\section{Results}

\section{Influence of foliar sulphur and its timings on phenological attributes and growth of wheat}

Application of foliar sulphur at higher rate of 21 and $15 \mathrm{~kg} \mathrm{ha}^{-1}$ delayed heading (121 days) and physiological maturity (161 and 160 days) compared to control, while the early heading (119 days) and maturity (156 days) was noted in control. Similarly, the application of sulphur at the time of tillering took more days to heading (120 days) and non-significant differences were found between full booting and two equal splits (50\% each at tillering and booting) respectively. Furthermore, sulphur application delayed maturity (159 days) at booting followed by tillering stage, while early maturity (157 days) was observed in sulphur application at two equal splits (50\% each at tillering and booting) as shown in Table 1 .

Table 1. Days to heading, days to maturity, plant height, internode length, tiller $\mathrm{m}^{-2}$, spike $m$ ${ }^{2}$ and grains spike ${ }^{-1}$ as affected by foliar sulphur and its application timing

\begin{tabular}{c|c|c|c|c|c|c|c}
\hline $\begin{array}{c}\text { Sulphur spray } \\
\left(\mathbf{k g ~ h a}^{-1)}\right.\end{array}$ & $\begin{array}{c}\text { Days to } \\
\text { heading }\end{array}$ & $\begin{array}{c}\text { Days to } \\
\text { maturity }\end{array}$ & $\begin{array}{c}\text { Plant height } \\
(\mathbf{c m})\end{array}$ & $\begin{array}{c}\text { Internode } \\
\text { length } \mathbf{( c m})\end{array}$ & $\begin{array}{c}\text { Tillers } \\
\mathbf{~ m}^{-2}\end{array}$ & $\begin{array}{c}\text { Spike } \\
\mathbf{m}^{-2}\end{array}$ & $\begin{array}{c}\text { Grains } \\
\mathbf{s p i k e}^{-\mathbf{1}}\end{array}$ \\
\hline Control & $119 \mathrm{c}$ & $156 \mathrm{c}$ & $92.1 \mathrm{~d}$ & 10.8 & $291 \mathrm{~d}$ & $283 \mathrm{c}$ & $52 \mathrm{c}$ \\
Water & $118 \mathrm{c}$ & $157 \mathrm{~b}$ & $94.3 \mathrm{c}$ & 10.8 & $309 \mathrm{c}$ & $307 \mathrm{~b}$ & $53 \mathrm{bc}$ \\
7.5 & $120 \mathrm{~b}$ & $158 \mathrm{~b}$ & $97.8 \mathrm{~b}$ & 11.1 & $319 \mathrm{~b}$ & $316 \mathrm{a}$ & $55 \mathrm{~b}$ \\
15 & $121 \mathrm{ab}$ & $160 \mathrm{ab}$ & $99.2 \mathrm{ab}$ & 10.7 & $320 \mathrm{~b}$ & $318 \mathrm{a}$ & $59 \mathrm{a}$ \\
21 & $123 \mathrm{a}$ & $161 \mathrm{a}$ & $100.3 \mathrm{a}$ & 11 & $323 \mathrm{a}$ & $309 \mathrm{~b}$ & $54 \mathrm{~b}$ \\
LSD & 1.1 & 1.3 & 2.5 & $\mathrm{~ns}$ & 10 & 11 & 2.6 \\
\hline Application timing (AT) & & & & & & & \\
\hline Tillering & $121 \mathrm{a}$ & $158 \mathrm{~b}$ & $95.3 \mathrm{~b}$ & 10.9 & $322 \mathrm{a}$ & $315 \mathrm{a}$ & $53 \mathrm{~b}$ \\
Booting & $120 \mathrm{~b}$ & $159 \mathrm{a}$ & $96.3 \mathrm{~b}$ & 10.9 & $310 \mathrm{~b}$ & $317 \mathrm{a}$ & $54 \mathrm{~b}$ \\
$1 / 2$ tillering + 1/2 booting & $120 \mathrm{~b}$ & $158 \mathrm{~b}$ & $98.7 \mathrm{a}$ & 10.8 & $295 \mathrm{c}$ & $288 \mathrm{~b}$ & $56 \mathrm{a}$ \\
LSD & 0.8 & 1 & 1.9 & $\mathrm{~ns}$ & 7 & 8 & 1.9 \\
\hline Interaction & & & & & & & \\
\hline S $\times$ AT & $* *$ & $* *$ & $\mathrm{~ns}$ & $\mathrm{~ns}$ & $\mathrm{~ns}$ & $\mathrm{~ns}$ & $\mathrm{~ns}$ \\
\hline
\end{tabular}

Means of the same category followed by different letters are significantly different from each other using LSD test $(\mathrm{P} \leq 0.05)$. ns stands for non-significant data and $* *$ indicates that data is significant at $1 \%$ level of probability 
Interaction between $\mathrm{S} \times \mathrm{AT}$ indicted that the maximum days to heading and maturity were recorded with the application of sulphur at the rate of $21 \mathrm{~kg} \mathrm{ha}^{-1}$ half at tillering half at booting was applied as shown in Figures 1 and 2. Compared to control (CK) the application of sulphur at the rate of $21 \mathrm{~kg} \mathrm{ha}^{-1}$ produced taller plants $(100 \mathrm{~cm})$, which was followed by $15 \mathrm{~kg} \mathrm{ha}^{-1}$, while dwarf plants $(92 \mathrm{~cm})$ and minimum internode length were recorded in control plot. Split application of sulphur $(50 \%$ each at tillering and booting) produced the tallest plants $(98 \mathrm{~cm})$, while lowest plant height $(95 \mathrm{~cm})$ was recorded in plots treated with sulphur at the time of tillering. There were generally nosignificant differences among foliar sulphur and its application timing for internode length of wheat. The application of foliar sulphur at $21 \mathrm{~kg} \mathrm{ha}^{-1}$ produces maximum tillers $\mathrm{m}^{-2}$ (323), however, the application of sulphur at 15 and $7.5 \mathrm{~kg} \mathrm{ha}^{-1}$ were statistically similar in response to tillers $\mathrm{m}^{-2}$ (320 and 319) compared to control. The spike $\mathrm{m}^{-2}$ and grain spike were statistically observed maximum (318 and 55) at the rate of $15 \mathrm{~kg} \mathrm{ha}^{-1}$ while lowest (283 and 52) at control respectively (Table 1).

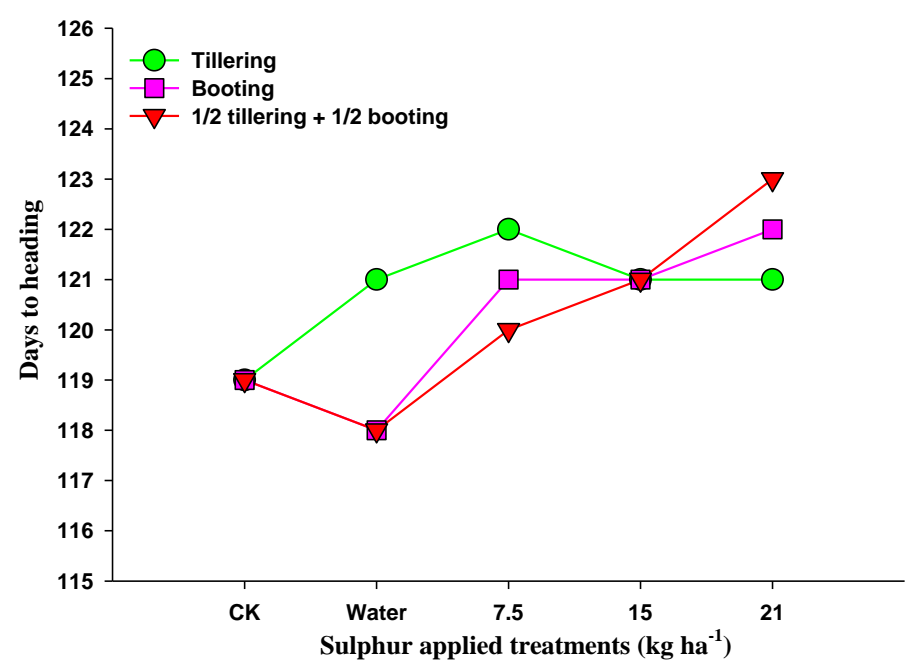

Figure 1. Response of days to heading of wheat to sulphur levels and application timing ( $S \times$ AT)

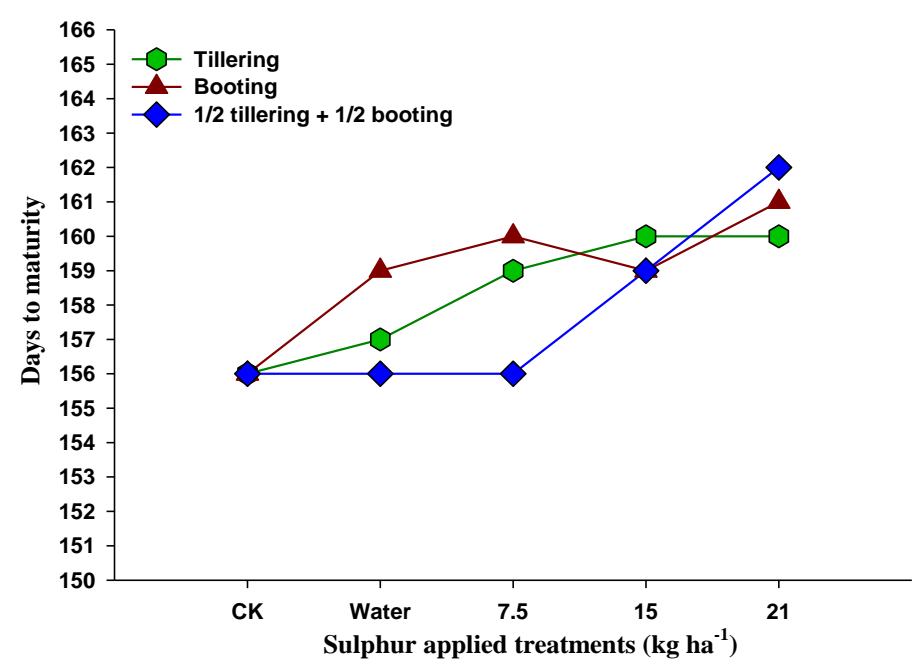

Figure 2. Response of days to maturity of wheat to sulphur levels and application timing ( $S \times$ $A T)$ 


\section{Influence of foliar sulphur and its timings on yield components of wheat}

Thousand grain weight were maximum (48 g) with the application of $15 \mathrm{~kg} \mathrm{~S} \mathrm{ha}^{-1}$ compared to control. The yield components (grain yield and biological yield) of wheat were increased $\left(31 \%\right.$ and $9 \%$ ) by the application of $15 \mathrm{~kg} \mathrm{ha}^{-1}$ compared to the control treatment. However, the following increasing trend $\left(15 \mathrm{~kg} \mathrm{ha}^{-1}>21 \mathrm{~kg} \mathrm{ha}^{-1}>7.5 \mathrm{~kg} \mathrm{ha}^{-1}\right.$ $>$ water spray > control) was observed for the yield components of wheat as shown in Table 2, respectively. The favorable stage for increasing the yield components (grain yield and biological yield) was noted where sulphur was applied in two equal splits (50\% each at tillering and booting). However, the interaction between sulphur and its application timing was found highest for thousand grains weight when sulphur was applied at the rate of $15 \mathrm{~kg} \mathrm{ha}^{-1}$ in two equal splits (Fig. 3). Analysis of correlation between soil sulphur and grain yield showed strong relationship at $\mathrm{R}^{2}=0.76$, and $\mathrm{P}<0.0001$ (Fig. 4). The harvest index was found to be highest (41\%) with the application of sulphur at the rate of $15 \mathrm{~kg} \mathrm{ha}^{-1}$ and was also highest when sulphur was applied in two equal splits (50\% each at tillering and booting) stage.

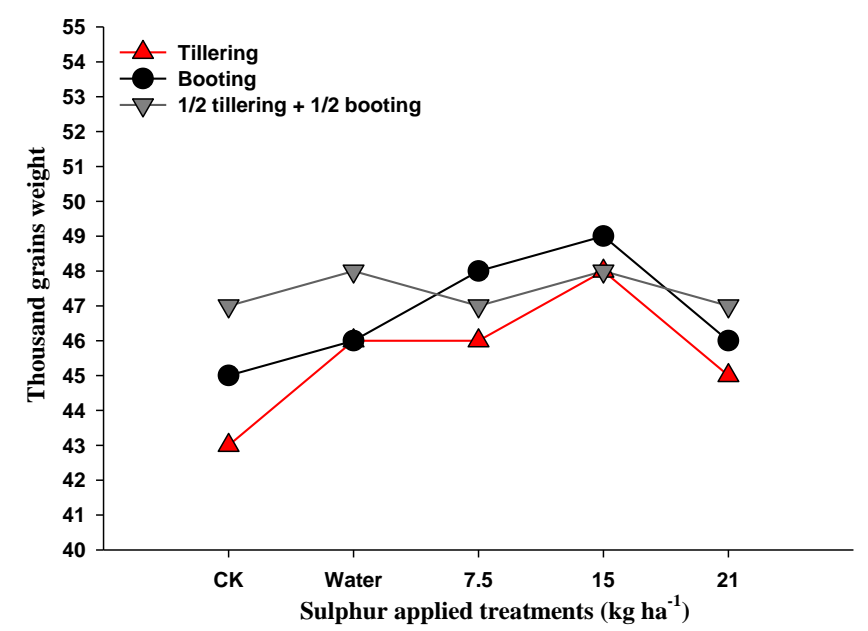

Figure 3. Response of thousand grains weight of wheat to sulphur levels and application timing $(S \times A T)$

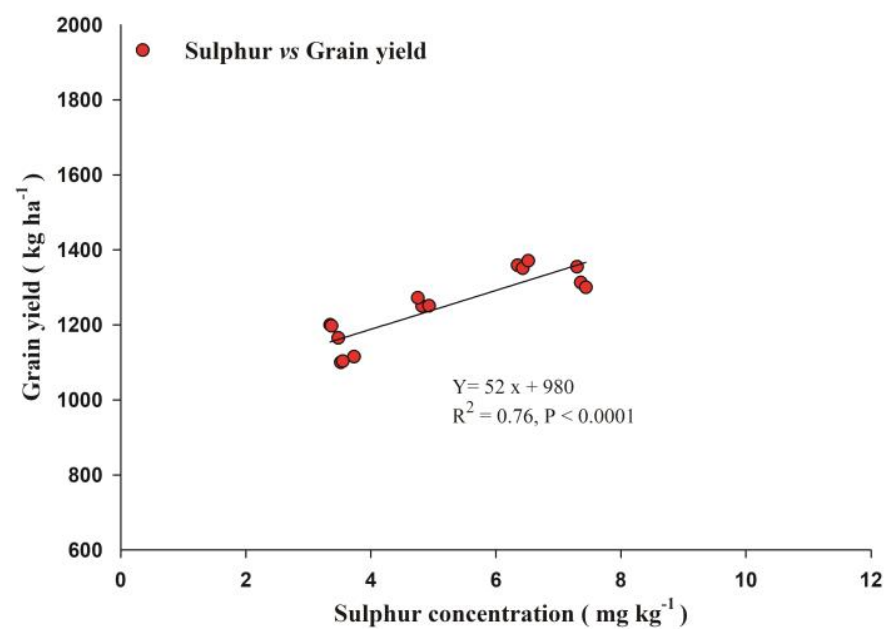

Figure 4. Correlation of sulphur with grain yield 
Table 2. Thousand grains weight ( $\mathrm{g})$, biological yield $\left(\mathrm{kg} \mathrm{ha}^{-1}\right)$, grain yield $\left(\mathrm{kg} \mathrm{ha} \mathrm{a}^{-1}\right)$, harvest index (\%) as affected by foliar sulphur and its application timing

\begin{tabular}{|c|c|c|c|c|}
\hline $\begin{array}{c}\text { Sulphur spray } \\
\left(\mathrm{kg} \mathrm{S} \mathrm{ha}^{-1}\right)\end{array}$ & $\begin{array}{c}\text { Thousand grains } \\
\text { weight (g) }\end{array}$ & $\begin{array}{c}\text { Biological yield } \\
\left(\mathrm{kg} \mathrm{ha}^{-1}\right)\end{array}$ & $\begin{array}{c}\text { Grain yield } \\
\left(\mathrm{kg} \mathrm{ha}^{-1}\right)\end{array}$ & $\begin{array}{c}\text { Harvest index } \\
(\%)\end{array}$ \\
\hline Control & $45.1 \mathrm{c}$ & $9347 \mathrm{c}$ & $3168 \mathrm{c}$ & $33.9 \mathrm{c}$ \\
\hline Water & $46.7 \mathrm{bc}$ & $9402 \mathrm{c}$ & $3622 b$ & $38.5 \mathrm{~b}$ \\
\hline 7.5 & $47.3 \mathrm{~b}$ & $9769 \mathrm{~b}$ & $3791 \mathrm{~b}$ & $38.8 \mathrm{~b}$ \\
\hline 15 & $48.4 \mathrm{a}$ & $10187 \mathrm{a}$ & $4145 \mathrm{a}$ & $40.8 \mathrm{a}$ \\
\hline 21 & $45.3 \mathrm{c}$ & $9928 \mathrm{ab}$ & $3923 \mathrm{ab}$ & $39.5 \mathrm{ab}$ \\
\hline LSD & 1.14 & 362 & 213 & 2.4 \\
\hline \multicolumn{5}{|l|}{ Application timing (AT) } \\
\hline Tillering & $45.4 \mathrm{~b}$ & $9526 \mathrm{~b}$ & $3585 \mathrm{~b}$ & 37.6 \\
\hline Booting & $46.8 \mathrm{ab}$ & $9750 \mathrm{ab}$ & $3694 \mathrm{ab}$ & 37.8 \\
\hline $1 / 2$ tillering $+1 / 2$ booting & $47.6 \mathrm{a}$ & 9902 a & 3910 a & 39.5 \\
\hline LSD & 0.9 & 280 & 165 & ns \\
\hline \multicolumn{5}{|l|}{ Interaction } \\
\hline $\mathrm{S} \times \mathrm{AT}$ & $*$ & $\mathrm{~ns}$ & $\mathrm{~ns}$ & ns \\
\hline
\end{tabular}

Means of the same category followed by different letters are significantly different from each other using LSD test $(\mathrm{P} \leq 0.05)$. ns stands for non-significant data and * indicates that data is significant at $5 \%$ level of probability

\section{Influence of foliar sulphur and its timings on soil and plant sulphur concentration (mg $\mathrm{kg}^{-1}$ )}

The influence of foliar sulphur and its timing on the soil post-harvest $S\left(\mathrm{mg} \mathrm{kg}^{-1}\right)$ and plant-post harvest $\mathrm{S}$ is shown in Figure $5 a, b$. It was observed that application of sulphur at the rate of $21 \mathrm{~kg} \mathrm{ha}^{-1}$ increased the sulphur concentration in soil and plant (104 and 195\%) which was followed by $15 \mathrm{~kg} \mathrm{ha}^{-1}$ in both the soil and plant postharvest (78 and 166\%) compared to control respectively. However, sulphur applied in two splits (50\% each at tillering and booting) was the significant stage which increased the sulphur concentration in soil as well as in the plant. Furthermore, it was observed that booting stage followed the two splits stage and increased the concentration of sulphur in soil post-harvest while tillering stage followed the two split stage and increased the sulphur concentration in plant. Overall the same trend was observed for soil and plant as $\left(21 \mathrm{~kg} \mathrm{ha}^{-1}>15 \mathrm{~kg} \mathrm{ha}^{-1}>7.5 \mathrm{~kg} \mathrm{ha}^{-1}>\mathrm{CK}>\right.$ water $)$.

\section{Discussion}

To situate the problem addressed here it was noted that the higher dose of S delayed the phenology which might be due to more vegetative growth of plants (Hussain and Leitch et al., 2005). However, reducing the sulphur levels can delay the aging of wheat crop. These findings are in line with Lestache et al. (2004). Moreover, Nawaz et al. (1989) and Khaliq et al. (2008) have also reported that the application of macronutrients delayed the phenology of crops (Lestache et al., 2004; Fageria, 2009). The application of $\mathrm{S}$ in two splits at the rate of $21 \mathrm{~kg} \mathrm{ha}^{-1}$, significantly increased wheat growth. The most possible reason behind this might be the split application of $S$ at different growth stages that matches with the nutrient requirement of the crop. These findings support the 
previous results of (Togay et al., 2008), they noted that sulphur application significantly increased the plant height and growth of wheat. Foliar application of nutrients enhances nutrient availability to main crops. We found increased $\mathrm{S}$ concentration in wheat plants upon foliar $\mathrm{S}$ application. Our results are in line with those reported by Laura et al. (2011) and Marinaccio et al. (2015). Recently, Aziz et al. (2018) reported increased growth, yield and nutrients concentration of wheat under the foliarly applied micronutrients spray at various wheat growth stages.
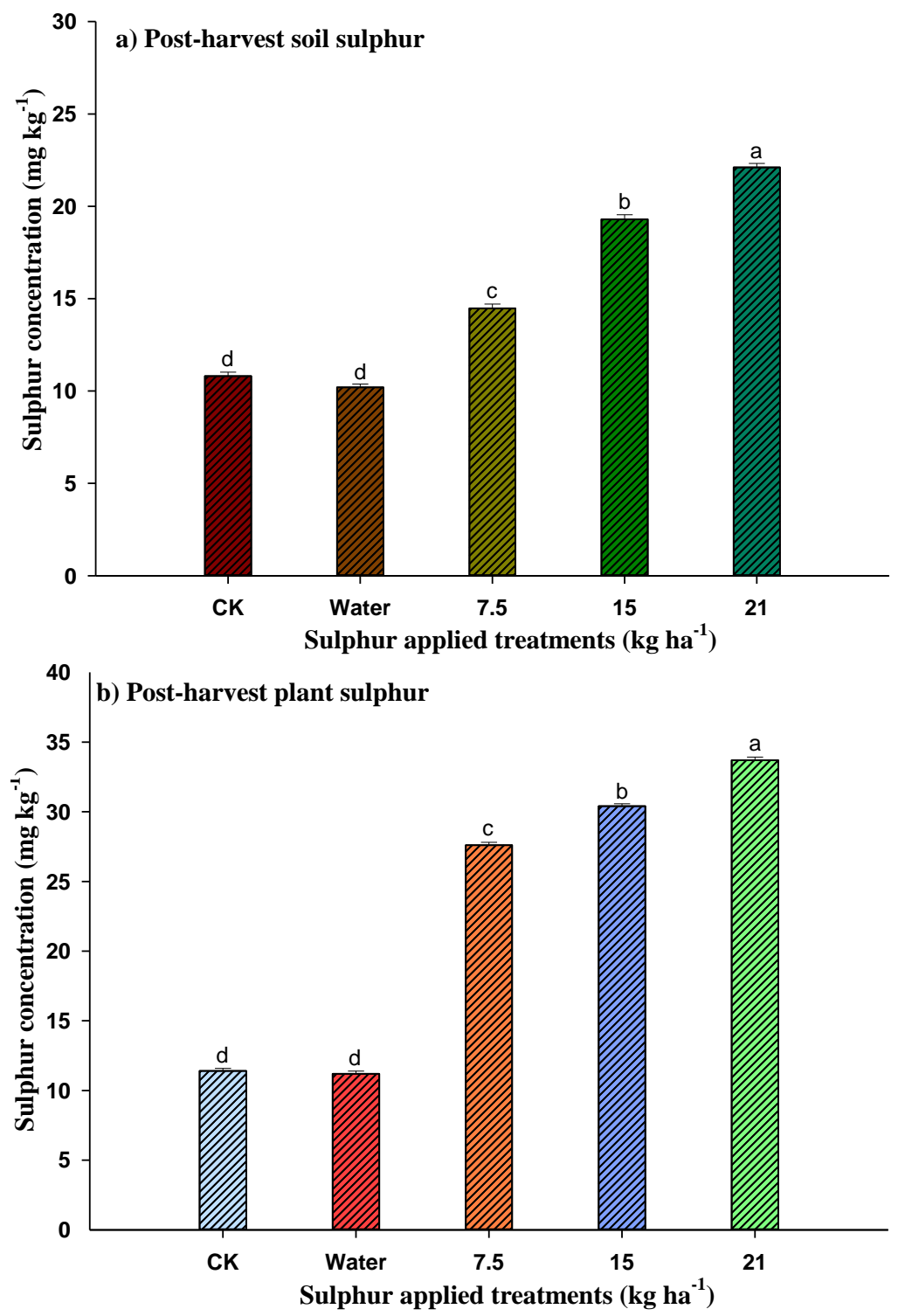

Figure 5. (a) Post-harvest soil sulphur concentration $\left(\mathrm{mg} \mathrm{kg}^{-1}\right)$. (b) Post-harvest plant sulphur concentration $\left(\mathrm{mg} \mathrm{kg}^{-1}\right)$

The higher dose of sulphur, increased the number of grains per row was mainly attributed due to the increase of panicle length. These findings are similar to those reported by Mahmood (1994), Rasheed et al. (2003) and Khaliq et al. (2009). Similar results were also documented by Ali et al. (2012), who indicated that application of sulphur significantly improved the number of tillers $\mathrm{m}^{-2}$. Pasha et al. (2006) in another 
study reported that the application of sulphur increased the panicle length and thousand grains weight of wheat. Laura et al. (2011) also reported that application of sulphur at the rate of $15 \mathrm{~kg} \mathrm{ha}^{-1}$ increased the concentration of sulphur in leaves and thousand grains weight in different stages.

Sulphur application at the rate of $15 \mathrm{~kg} \mathrm{ha}^{-1}$, divided into two equal amounts $(50 \%$ at tillering stage and $50 \%$ at booting stage), significantly increased grain yield, biological yield and yield index of wheat. These results are substantiated with Saeed et al. (2013). Ramos et al. (2008) emphasized that the application of $S$ in tillering could improve grain yield. One possible reason for this might be that when the leaves absorbed sulphur, they produce methionine, a biological precursor of ethylene (Saeed et al., 2013). The beneficial effect of the number of panicles on flowering biomass was greater than that of grain yield, which indicated that the number of panicles had a strong correlation with the source vigor and was also restricted by the environment. Hussain and Leitch (2005), Khan et al. (2006) and Ercoli et al. (2011) found that the application of sulphur can significantly increase the wheat grain yield and straw yield. Dorothee et al. (2012) reported the beneficial effects of sulphur fertilizer on grain yield and protein composition of mature wheat.

Kulczycki (2010) described that maximum biological yield was observed when sulphur was applied in two equal splits half at tillering and half at booting. These findings are consistent with those given by Girma et al. (2005), who claimed that application of sulphur could increase the grain yield of wheat. In the same way, the maximum grain yield is pointed out that when sulphur application is applied in two splits and recorded the minimum yield of grain, when sulphur was applied to the crop at tillering stage at the same time Marinaccio et al. (2015) and Ercoli et al. (2012) reported that the $\mathrm{S}$ rate division and stem elongation before sowing were the highest in grain yield and plant absorption of $S$. The results showed that the harvest index value increased with the increase of $\mathrm{S}$ concentration. These findings are in line with those reported by (Hammad et al., 2011). Khan et al. (2006) in a similar study stated that the high dose of $\mathrm{S}$ will eventually improve the $\mathrm{SO}_{4}-\mathrm{S}$ content in the soil. Bharathi and Poongothai (2008) further claimed that the application of sulphur to soil improves the current status of $\mathrm{SO}_{4}-\mathrm{S}$ content which is ultimately linked to higher crop growth and yield responses.

\section{Conclusions}

It was concluded from the study that the foliar sulphur application improved growth, increased yield and yield components of wheat under semiarid climate of Peshawar, Pakistan. Application of $S$ at the rate of $15 \mathrm{~kg} \mathrm{ha}^{-1}$ was found more beneficial in terms of better growth, higher yield and yield components of wheat compared to control (no spray). However, post-harvest soil and plant sulphur concentration was maximum when sulphur was applied at the rate of $21 \mathrm{~kg} \mathrm{ha}^{-1}$. Among application timings, foliar application of sulphur at two equal splits (50\% each at tillering and booting) was a better time for improving growth, yield and yield components of wheat. Therefore, the application of sulphur at the rate of $15 \mathrm{~kg} \mathrm{ha}^{-1}$ is recommended as a foliar spray in two equal splits (50\% each at tillering and booting) to maximize not only growth and yield but also the level of sulphur in soil which will ultimately improve wheat production in local semiarid climate. 
Acknowledgements Financial support from the National Natural Science Foundation of China (41620104006 and 41571298) is gratefully acknowledged. Authors are highly grateful to the Higher Education Commission of Pakistan and University of Agriculture, Peshawar-KPK-Pakistan.

\section{REFERENCES}

[1] Ali, A., Arshadullah, M., Hyder, S. I., Mahmood, I. A. (2012): Effect of different levels of sulfur on the productivity of wheat in a saline sodic soil. - Soil \& Environment 31(1).

[2] Amanullah, K. R., Khalil, S. K. (2009): Effects of plant density and N on phenology and yield of maize. - J Plant Nutr 32: 246-260.

[3] Aziz, M. Z., Yaseen, M., Abbas, T., Naveed, M., Mustafa, A., Hamid, Y., Saeed, Q., Xu, M. (2018): Foliar application of micronutrients enhances crop stand, yield and the biofortification essential for human health of different wheat cultivars. - Journal of Integrative Agriculture 18(6): 1369-1378.

[4] Bharathi, C., Poongothai, S. (2008): Direct and residual effect of sulphur on growth, nutrient uptake, yield and its use efficiency in maize and subsequent green gram. Research Journal of Agriculture and Biological Sciences 4(5): 368-72.

[5] Chandio, A. A., Yuansheng, J., Magsi, H. (2016): Agricultural sub-sectors performance: an analysis of sector-wise share in agriculture GDP of Pakistan. - International Journal of Economics and Finance 8(2): 156-162.

[6] Clark, C. M., Tilman, D. (2008): Loss of plant species after chronic low-level nitrogen deposition to prairie grasslands. - Nature 451(7179): 712.

[7] Davidson, E. A. (2009); The contribution of manure and fertilizer nitrogen to atmospheric nitrous oxide since 1860. - Nat. Geosci. 2: 659-662.

[8] Diaz, R. J., Rosenberg, R. (2008): Spreading dead zones and consequences for marine ecosystems. - Science 321(5891): 926-929.

[9] Ercoli, L., Lulli, L., Arduini, I., Mariotti, M., Masoni, A. (2011): Durum wheat grain yield and quality as affected by $\mathrm{S}$ rate under Mediterranean conditions. - European Journal of Agronomy 35(2): 63-70.

[10] Fageria, N. K., Moreira, A. (2011): The role of mineral nutrition on root growth of crop plants. - Advances in Agronomy 110: 251-331.

[11] Garrido-Lestache, E., López-Bellido, R. J., López-Bellido, L. (2004): Effect of N rate, timing and splitting and $\mathrm{N}$ type on bread-making quality in hard red spring wheat under rainfed Mediterranean conditions. - Field Crops Research 85(2-3): 213-236.

[12] Gee, G. W., Bauder, J. W. (1979): Particle size analysis by hydrometer: a simplified method for routine textural analysis and a sensitivity test of measurement parameters. Soil Sci Soc Am J 43: 1004-1007

[13] Girma, K., Mosali, J., Freeman, K. W., Raun, W. R., Martin, K. L., Thomason, W. E. (2005): Forage and grain yield response to applied sulfur in winter wheat as influenced by source and rate. - Journal of Plant Nutrition 28(9): 1541-1553.

[14] Government of Pakistan (GOP) (2015): Economic Survey of Pakistan. - Ministry of Food, Agriculture and Livestock, Federal Bureau of Statistics 2014-15.

[15] Guo, J. H., Liu, X. J., Zhang, Y., Shen, J. L., Han, W. X., Zhang, W. F., Christie, P., Goulding, K. W. T., Vitousek, P. M., Zhang, F. S. (2010): Significant acidification in major Chinese croplands. - Science 327(5968): 1008-1010.

[16] Győri, Z. (2005): Sulphur content of winter wheat grain in long term field experiments. Communications in Soil Science and Plant Analysis 36(1-3): 373-382.

[17] Hammad, H. M., Ahmad, A., Khaliq, T., Farhad, W., Mubeen, M. (2011): Optimizing rate of nitrogen application for higher yield and quality in maize under semiarid environment. - Crop Environ 2(1): 38-41. 
[18] Hussain, Z., Leitch, M. H. (2005): The effect of applied sulphur on the growth, grain yield and control of powdery mildew in spring wheat. - Annals of Applied Biology 147(1): 49-56.

[19] Iqbal, A., Hidayat, Z. (2016): Potassium management for improving growth and grain yield of maize (Zea mays L.) under moisture stress condition. - Scientific Reports 6: 34627.

[20] Kakar, K. M., Saleem, M., Iqbal, A. (2015): Effect of irrigation levels and planting methods on phenology, growth, biomass and harvest index of spring wheat under semiarid condition. - Pure and Applied Biology 4(3): 375.

[21] Khaliq, T., Ahmad, A., Hussain, A., Ranjha, A. M., Ali, M. A. (2008): Impact of nitrogen rates on growth, yield, and radiation use efficiency of maize under varying environments. - Pak. J. Agri. Sci 45(3): 1-7.

[22] Khaliq, T., Ahmad, A., Hussain, A., Ali, M. A. (2009): Maize hybrids response to nitrogen rates at multiple locations in semiarid environment. - Pak. J. Bot 41(1): 207-224.

[23] Khan, M. J., Hafeez, M. K., Khattak, R. A., Jan, M. T. (2006): Response of maize to different levels of sulfur. - Commun. Soil Sci. Plant Anal. 37(1): 41-51.

[24] Kulczycki, G. (2010): The Effect of Soil and Foliar Sulphur Application on Winter Wheat Yield and Soil Properties. - Wroclaw University of Environmental and Life Sciences, Wroclaw.

[25] MacRitchie, F., Gupta, R. B. (1993): Functionality-composition relationships of wheat flour as a result of variation in sulfur availability. - Australian Journal of Agricultural Research 44(8): 1767-1774.

[26] Mahmood, T. (1994): Impact of water and nutrient management on growth, yield and quality of maize (Zea mays L.) - Doctoral dissertation, University of Agriculture Faisalabad Pakistan.

[27] Malik, M. A., Irfan, M., Ahmed, Z. I., Zahoor, F. (2006): Residual effect of summer grain legumes on yield and yield components of wheat (Triticum aestivum L.). - Pakistan Journal of Agriculture, Agricultural Engineering and Veterinary Sciences 22(1): 9-11.

[28] Marinaccio, F., Reyneri, A., Blandino, M. (2015): Enhancing grain yield and quality of winter barley through agronomic strategies to prolong canopy greenness. - Field Crops Research 170: 109-118.

[29] Mengal, S. H., Kirkby, D. S. (1987): The role of sulphur to assess crop productivity. - J. Agric. Biol. 773-789(7): 137-190.

[30] Mustafa, A., Naveed, M., Saeed, Q., Ashraf, M. N., Hussain, A., Abbas, T., Kamran, M., Sun, N., Xu, M. (2019a): Application Potentials of Plant Growth Promoting Rhizobacteria and Fungi as an Alternative to Conventional Weed Control Methods. InTechOpen, London.

[31] Mustafa, A., Naveed, M., Abbas, T., Saeed, Q. (2019b): Growth response of wheat and associated weeds to plant antagonistic rhizobacteria and fungi. - Italian Journal of Agronomy 14(4): 191-198.

[32] Nawaz, A. (1989): Effect of time and method of fertilizer application on the growth and yield potential of maize. - M.Sc. Thesis, Univ. Agric. Faisalabad.

[33] Pasha, A., Chittapur, B. M., Patil, B. N., Hiremath, S. M. (2010): Effect of prolonged nitrogen application and sulphur nutrition on grain quality and nutrient uptake of wheat and soil available nutrient dynamics. - Karnataka Journal of Agricultural Sciences 20(2).

[34] Pathak, H., Wasmann, C. R., Ladha, J. K. (2006): Stimulation of nitrogen balances in rice-wheat system of the Indo-Gangetic Plains. - Soil Sci. Soc. Agric. J. 70: 1612-1622.

[35] Ramos, J. M., Garcia Del Moral, L. F., Molina-Cano, J. L., Salamanca, P., De-Togores, F. R. (2008): Effects of an early application of sulphur or Ethephon as foliar spray on the growth and yield of spring barley in a Mediterranean environment. - J. Agron. Crop Sci. 163(2): 129-137. 
[36] Rasheed, M., Mahmood, T., Nazir, M. S. (2003): Response of hybrid maize to different planting methods and nutrient management. - Pakistan Journal of Agricultural Sciences 40(1-2): 39-42.

[37] Rashid, A. 1986. Mapping zinc fertility of soils using indicator plants and soil analyses. Doctoral dissertation, University of Hawaii, Manoa.

[38] Rayan, J., Garabet, S., Rashid, A., EI-Gharous, M. (2001): Soil test celebration workshop in West Asia - North Africa. - Proc. 3rd Regional Workshop. Amman, Jordan, Sept. 3-9 1988, ICARDA, Aleppo, Syria.

[39] Richard, L. A. (1954): Diagnostic and Improvement of Saline and Alkali Soils. - Agric. Handbook 60, USDA, Washington, DC.

[40] Ryant, P., Hrivna, L. (2004): The effect of sulphur fertilization on yield and technological parameters of spring wheat grain. - Annales Universitatis Mariae Curie-Sklodowska Sectio E Agricultura 59(4): 1669-1678.

[41] Saeed, B., Gul, H., Khan, A. Z., Parveen, L. (2012): Growth factors and straw yield of wheat cultivars in relation with nitrogen and sulfur fertilization. - APRN Journal of Agricultural and Biological Science 7(1).

[42] Saeed, B., Khan, A. Z., Khalil, S. K., Rahman, H. U., Ullah, F., Gul, H., Akbar, H. (2013): Response of soil and foliar applied nitrogen and sulfur towards yield and yield attributes of wheat cultivars. - Pak. J. Bot 45(2): 435-442.

[43] Simard, R. (1993): Ammonium Acetate-Extractable Elements. - In: Carter, M. R. (ed.) Soil Sampling and Methods of Analysis. Lewis Publisher, Boca Raton, pp. 39-42.

[44] Singh, B. R. (2003): Sulfur and Crop Quality-Agronomical Strategies for Crop Improvement. - COST Action 829 Meetings, Braunschweig, Germany, May 15-18, 2003, pp. $15-18$.

[45] Soltanpour, P. N. (1985): Use of ammonium bicarbonate DTPA soil test to evaluate elemental availability and toxicity. - Communications in Soil Science and Plant Analysis 16(3): 323-338.

[46] Steel, R. G., Torrie, J. H. (1980): Principles and Procedures of Statistics. A Biometrical Approach. $2^{\text {nd }}$ Ed. - McGraw-Hill Kogakusha, Tokyo.

[47] Steinfurth, D., Zörb, C., Braukmann, F., Mühling, K. H. (2012): Time-dependent distribution of sulphur, sulphate and glutathione in wheat tissues and grain as affected by three sulphur fertilization levels and late S fertilization. - Journal of Plant Physiology 169(1): 72-77.

[48] Tandon, H. L. S. (1984): Sulphur Research and Agricultural Production in India. Technical Report. - Fertiliser Development and Consultation Organisation, New Delhi.

[49] Tilman, D., Balzer, C., Hill, J., Befort, B. L. (2011): Global food demand and the sustainable intensification of agriculture. - Proceedings of the National Academy of Sciences 108(50): 20260-20264.

[50] Tisdale, S. L., Nelson, W. L., Beaton, J. D. (1985): Soil Fertility and Fertilizers. Macmillan, New York, pp. 75-79.

[51] Togay, Y., Togay, N., Cig, F., Erman, M., Celen, A. E. (2008): The effect of sulphur applications on nutrient composition, yield and some yield components of barley (Hordeum vulgare L.). - African Journal of Biotechnology 7(18).

[52] Watanabe, F. S., Olsen, S. R. (1965): Test of an ascorbic acid method for determining phosphorus in water and NaHCO3 extracts from soil. - Soil Sci Soc Am J 291: 677-678.

[53] Zhao, F. J., Hawkesford, M. J., McGrath, S. P. (1999): Sulphur assimilation and effects on yield and quality of wheat. - Journal of Cereal Science 30(1): 1-17. 